\title{
Economical Comparison of Different Production Models in Edible Vine Leaf Production
}

\author{
Mehmet Ali Kiracı $^{\text {** (iD) }}$,Mehmet Ali Şenol $^{\mathbf{1}}$, Uğur Akdemir ${ }^{\mathbf{1}}$ (iD \\ ${ }^{1}$ Tekirdağ Viticulture Research Institute
}

How to cite: Kiracı, M. A., Şenol, M. A., \& Akdemir, U. (2022). Economical comparison of different production models in edible vine leaf production. Viticulture Studies (VIS), 2(1), 13- 23. https://doi.org/10.52001/vis.2022.7.13.23

\section{Article History:}

Received: 29.11.2021

Accepted: 29.12 .2021

First online: 07.01.2022

\section{Corresponding Author}

mehmetali.kiraci@tarimorman.gov.tr

\begin{abstract}
This study aims to determine the production model providing the maximum economic benefit to the producers by comparing the harvesting models comprising different amounts of grape load and different number of harvested leaves of Yapıncak variety. This variety is one of the important grape varieties whose leaves are evaluated as edible/pickled. 12 different production models, 10 models targeting grape and leaf harvesting together, and 2 models harvesting only leaves and only grapes were established in the trial vineyard consisting of vines of the same age. Production and variable costs, gross production values (GPV), gross and net profits and proportional profitability were calculated for the unit area of production models. The study was conducted in 2018 and 2019 years. In 2018, the production model in which all the grapes were not harvested and the leaves were harvested 5 times had the highest values with a net profit of $1.166,5$ TRY and proportional profitability of 1.57. In 2019, the model, in which grapes were harvested at a rate of $50 \%$ and the leaves were harvested 7 times, became the economically recommended variety for producers with a net profit of 4.664,3 TRY and proportional profitability of 2.69. It has been determined that although the quality of the grapes decreases as the number of grapes which are not harvested in the grapevines increases, the quality of the leaves has not decreased due to the number of harvests.
\end{abstract}

\section{Keywords}

Grapevine leaves

Yapıncak

Grape variety

Relative profitability required to mark the harmony of the local ecology and the difference of the product quality. In this context, as a result of the application of the Erbaa Chamber of Industry and Commerce in Tokat province, "Erbaa Narince Vineyard Leaf" was registered as a geographical sign on $5^{\text {th }}$ of December 2017 in the type of origin name (TUIK, 2017). The application of the leaf of Yapıncak grape variety by the Süleymanpaşa Chamber of Agriculture in Tekirdağ province with the same purpose was registered as "Tekirdağ Yapıncak Brined Grapevine Leaf" on $28^{\text {th }}$ of October 2020.

It is desirable that the leaves to be pickled should be thin, less hairy, and as whole as possible without slices. Today, the most preferred and prominent varieties in the production of brine and canned grapevine leaf in Turkey are Sultani Çekirdeksiz in the Aegean region, Narince in the 
Table 1. Vine leaves exports of Turkey

\begin{tabular}{lll}
\hline Years & $\begin{array}{l}\text { Export Amount } \\
(\mathbf{k g})\end{array}$ & $\begin{array}{l}\text { Export Value } \\
\text { (USD) }\end{array}$ \\
\hline 2013 & 26.178 & 54.878 \\
2014 & 37.014 & 89.038 \\
2015 & 41.748 & 79.611 \\
2016 & 60.152 & 102.881 \\
2017 & 118.505 & 258.161 \\
2018 & 415.096 & 223.786 \\
2019 & 269.077 & 281.110 \\
\hline
\end{tabular}

TUIK 2019

Tokat region, and Yapıncak in the Thrace region (Çelik et al., 2010).

In a study conducted in Tokat in 2011, six different production models of Narince grape variety, which include two different levels of brined leaves (three and five periods) and the harvest of grapes (ripe and unripe) in different periods, were compared in terms of gross and net profit. It was concluded that the combination of brined leaves and ripe grapes have the highest values (Cangi et al., 2011). According to to data issued by Turkish Statistical Institute (TSI), the amount of grapevine leaves exported by Turkey has increased continuously especially after 2013, and exceeded 11 times of the export amount in 2019 compared to 2013. In addition, the export value reached $\$ 281.110$, as the highest value of the period as of last year (Table 1).

This economic value of vine leaves has resulted in the gradual widespread use of byproduct viticulture by collecting young leaves in addition to the main product grape. Especially in the district of Erbaa, cultivation has emerged that consideres vine leaves as the main product and aims to harvest the only leaves by cutting and removing the bunches in the early period. For this reason, the majority of producers seek answers to what rate they can leave their grapes, to what point they can take the grape and leaf harvest together, how many times the leaves are harvested on their vines and how many grapes should be left in order to get the highest income per unit area.

In this study, it was aimed to determine the production model providing the highest economic benefit to the producers by comparing the production models with different amounts of grape load and a different number of leaves harvested in terms of economic.

\section{Material and Methods}

\section{Material}

The material of the study consists of the data obtained on the grape and leaves harvested for two years from the trial vineyard established from the Yapıncak grape variety, which is widely grown for edible leaf production. Yapıncak variety is mainly grown for wine. The grapes from the leaf-picked vineyards can be used in the production of molasses or vinegar.

12 different production models, 10 models targeting grape and leaf harvesting together, and 2 models harvesting only leaves and only grapes were established in the trial vineyard consisting of vines of the same age. While the amount of grapes in the models is limited to leaving the bunches of the vines at varying rates depending on the models, the others are removed from the vine, a varying number of leaves still were harvested depending on the model. To obtain the appropriate data, the harvesting models in the experiment were designed for a total of 12 vines, with three repetitions and four vines per repetition.

Harvesting models are below;

1. From each grapevine; 3 times leaf harvest + Full grape harvest (L3-G100)

2. From each grapevine; 3 times leaf harvest $+25 \%$ reduced grape harvest (L3-G25)

3. From each grapevine; 3 times leaf harvest $+50 \%$ reduced grape harvest (L3-G50) 
4. From each grapevine; 3 times leaf harvest $+75 \%$ reduced grape (L3-G75)

5. From each grapevine; 5 times leaf harvest + Full grape harvest (L5-G100)

6. From each grapevine; 5 times leaf harvest $+25 \%$ reduced grape harvest (L5-G25)

7. From each grapevine; 5 times leaf harvest $+50 \%$ reduced grape harvest (L5-G50)

8. From each grapevine; 5 times leaf harvest $+75 \%$ reduced grape harvest (L5-G75)

9. From each grapevine; 7 times leaf harvest $+50 \%$ reduced grape harvest (L7-G50)

10. From every grapevine; 7 times leaf harvest $+75 \%$ reduced grape harvest (L7-G75)

11. Only harvesting leaves (as much as possible) by taking whole bunches of grapes from each grapevine. (L)

12. Only grape harvest without harvesting any leaves from each grapevine. (G)

The number of grapes in the grapevines was adjusted by leaving the clusters in the proportions determined in the models and removing the grape grains from the grapevine with the cluster scissors when the grape grains of the others are 2-3 $\mathrm{mm}$ in diameter. Besides, all cultural processes such as tillage, hoeing, weed control, and plant feeding in the vineyard were carried out homogeneously (equally) in terms of method, amount, dose, and time. Summer pruning processes such as sprout, seat, leaf and hill removal were applied at varying times depending on the harvesting models.

Leaf harvesting started approximately 10 days before the beginning of flowering and continued with 7 days intervals until 20 days (approximately 60 days) before the veraison of the grapes.

Healthy leaves were harvested when they reached the size of $1 / 3$ to $2 / 3$ of the mature leaf. The stalks of the collected leaves are shortened by $1-2 \mathrm{~cm}$.

When grapes reached the level of 11-12 bome determined for the maturity criterion for white wine grapes, all production models were collected at the same time with the help of a pair of scissors. Harvested grapes were classified as first for wine, and then for grape juice (molasses).

\section{Method}

The data obtained from the trial vineyard according to harvesting models were gradually subjected to economic analysis within the scope of the details given below.

1. Production Costs (TRY)

Production Costs $\left(\right.$ TRY da $\left.{ }^{-1}\right)=$ Variable Costs $\left(\right.$ TRY da $\left.{ }^{-1}\right)+$ Fixed Costs (TRY da $\left.{ }^{-1}\right)$

Unit Costs (TRY kg-1) $=$ Production Costs $\left(\right.$ TRY $\left.\mathrm{da}^{-1}\right) /$ Yield $\left(\mathrm{kg} \mathrm{da}^{-1}\right)$

Facility costs, include labor and its expenses, material costs, and variable capital. In determining the elements that make up the variable cost group, the cost value for raw materials and auxiliary materials procured from outside and the farmyard price for those procured from the enterprise was taken as a basis. $3 \%$ of the total variable costs were calculated as general administrative expenses. Half of the interest rate of Ziraat Bank for plant production loans in the same year has been taken into account for the variable costs in determining the variable capital interest. Land rent was taken as $5 \%$ of the interest of bare field (Demircan et al., 2005)

As variable costs, labor expenses; summer and winter pruning, soil preparation, planting, fertilization, irrigation, hoeing, spraying and harvesting, material expenses; vineyard post, vineyard wire; sapling, fertilizers, medicine and fuel, other expenses; It consists of land rent, tool-machine rent and other direct expenses (Birinci et al., 2006).

2. Gross Production Value $\left(T R Y d a^{-1}\right)=$ Yield ( $\mathrm{kg} \mathrm{/} \mathrm{da)} x$ Sales Price (TRY $\mathrm{kg}^{-1}$ ) + Productive value increase

3. Gross Profit (TRY $\left.\mathrm{da}^{-1}\right)=$ \{Gross Production Value (TRY da $\left.{ }^{-1}\right)$ - Variable Costs (TRY $\left.\left.\mathrm{da}^{-1}\right)\right\}+$ Productive value increase

Since productive value increases in very low level it was not calculated.

4. Net Profit (TRY da $\left.{ }^{-1}\right)=$ Gross Production Value (TRY da-1) - Production Costs $\left.\left(T R Y d^{-1}\right)\right\}$ Productive value increase

5. Relative Profit $=$ Gross Production Value (TRY da-1) / Production Costs (TRY da-1)

In the study, male labor force was taken into account in the cost calculations of labor force, and quantity records were calculated by adapting the unit area. The cost is calculated according to the labor prices (wage) at the time of the work. The current market pricing technique has been chosen as the evaluation 
method of the harvested grapes to be used as wine or molasses and then they were priced and subjected to economic analysis. The edible leaves are priced over the current prices received by the producer.

\section{Results and Discussion}

\section{Leaf and Grape Harvest and Yields}

Leaf harvest started in the first year of the study on May 23, and on July 23, it was completed with the 9th leaf harvest, which was only leaf harvested. The second-year, it started on May 30 and August $5^{\text {th }}$, it was completed with the $9^{\text {th }}$ leaf harvest, which was only leaf harvested.

The grape harvest was carried out in the first year of the study by making all the models on the same day on $12^{\text {th }}$ of September 2018, and it was decided to evaluate all the grapes in the all production models as molasses in terms of their quality and the value of the grape was calculated from the market price of molasses grape. The second year, it was held on 3 separate dates depending on the maturity monitoring of production models. On September 20, 25\% (G25) per grapevine and on September 23, 50\% grape per grapevine were harvested, while on
September 25, the grape harvest was made in other production models. Since the grapes of the models in which the grape load is left at the rates of $25 \%$ and $50 \%$ meet the wine quality criteria, these grapes are priced at the current price for wine, and the grapes harvested from other models for molasses are priced at current prices and subjected to economic analysis. However, there were no differences between the quality of the harvested leaves, depending on the number of harvests and grape load.

Table 2 shows the grape and leaf yields harvested from the production models in 2018 and 2019. It is seen that the predicted number of leaf harvests and the rate of grapes left are decisive in the production models. The yield of leaves is parallel to the increase in the number of harvests, and the yield of grapes is parallel to the number of clusters left on the vines. While it approaches $250 \mathrm{~kg} \mathrm{da}^{-1}$ in the leaf harvested model, it exceeds $13.50 \mathrm{~kg}$ vine $^{-1}$ in the grape harvesting model.

\section{Economic Analysis}

In the economic analysis, at first, it was tried to be determined the costs of the transactions made in the trial vineyard the materials used, and the labor force. Then, the

Table 2. Grape and leaf yield in harvesting models

\begin{tabular}{llllc}
\hline \multirow{2}{*}{ Production Models } & \multicolumn{3}{c}{$\begin{array}{c}\text { Grape Yield } \\
\text { (kg vine-1) }\end{array}$} & \multicolumn{2}{c}{$\begin{array}{c}\text { Leaf Yield } \\
\text { (kg da-1) }\end{array}$} \\
\cline { 2 - 5 } & $\mathbf{2 0 1 8}$ & $\mathbf{2 0 1 9}$ & $\mathbf{2 0 1 8}$ & $\mathbf{2 0 1 9}$ \\
\hline L3-G100 & 10.524 & 9.330 & 41.501 & 56.385 \\
L3-G75 & 8.228 & 8.637 & 40.105 & 47.667 \\
L3-G50 & 8.087 & 8.467 & 44,399 & 59.487 \\
L3-G25 & 7.237 & 6.100 & 47.880 & 82.992 \\
L5-G100 & 11.164 & 9.597 & 54.728 & 74.585 \\
L5-G75 & 9.106 & 9.380 & 75.711 & 91.115 \\
L5-G50 & 8.875 & 8.127 & 98.876 & 105.745 \\
L5-G25 & 6.144 & 5.243 & 87.529 & 96.900 \\
L7-G50 & 6.713 & 10.080 & 128.600 & 142.786 \\
L7-G25 & 5.417 & 5.263 & 118.081 & 123.606 \\
G & 10.792 & 13.573 & - & - \\
L & - & - & 186.208 & 249.930 \\
\hline
\end{tabular}


Table 3. Pricing of income and expense elements

\begin{tabular}{|c|c|c|}
\hline \multicolumn{3}{|l|}{ Market current prices of income items } \\
\hline Income element & Manufacturer received price & \\
\hline Molasses grape & Year of 2018: 1.00 TRY $\mathrm{kg}^{-1}$ & Year of 2019: $1.30 \mathrm{TRY}_{\mathrm{kg}}{ }^{-1}$ \\
\hline Wine grape & Year of 2019: $2.30 \mathrm{TRY} \mathrm{kg}^{-1}$ & \\
\hline Fresh leaf & Year of 2018: $12.00 \mathrm{TRY} \mathrm{kg}^{-1}$ & Year of 2019: $15.00 \mathrm{TRY} \mathrm{kg}^{-1}$ \\
\hline \multicolumn{3}{|c|}{ Market current prices of expense elements (2018 and 2019 years) } \\
\hline Expense element & 2018 Year & 2019 Year \\
\hline Labor & 80.00 TRY day ${ }^{-1}$ & 100.00 TRY day ${ }^{-1}$ \\
\hline Winter pruning work & 100.00 TRY day ${ }^{-1}$ & 100.00 TRY day ${ }^{-1}$ \\
\hline Deep till & 40.00 TRY da-1 & $50.00 \mathrm{TRY} \mathrm{da}^{-1}$ \\
\hline Till with rotator & 20.00 TRY da-1 & 25,00 TRY da-1 \\
\hline Till with cultivator & $10.00 \mathrm{TRY}_{\mathrm{da}}^{-1}$ & 15.00 TRY $\mathrm{da}^{-1}$ \\
\hline Till with the discharrow & 15.00 TRY da-1 & $25.00 \mathrm{TRY}_{\mathrm{da}}{ }^{-1}$ \\
\hline Harrow & 7.50 TRY da-1 & 15.00 TRY da-1 \\
\hline Fertilization & $10.00 \mathrm{TRY} \mathrm{da}^{-1}$ & 10.00 TRY da-1 \\
\hline Plant protection & 10.00 TRY da-1 & 10.00 TRY da-1 \\
\hline Chemical fertilizer (15-15-15 Zn) & $0.75 \mathrm{TRY}_{\mathrm{kg}}{ }^{-1}$ & $0.81 \mathrm{TRY} \mathrm{kg}^{-1}$ \\
\hline Land rent & 500.00 TRY da-1 $^{-1}$ & $500.00 \mathrm{TRY}_{\mathrm{da}}^{-1}$ \\
\hline Facility depreciation (40 ears) & 120.00 TRY da-1 & 120.00 TRY da-1 \\
\hline Machine tool equipment depreciation (10 years) & 35.00 TRY $\mathrm{da}^{-1}$ & $35.00 \mathrm{TRY} \mathrm{da}^{-1}$ \\
\hline Pesticides & Purchase price & \\
\hline
\end{tabular}

revenues of the products obtained with the production values, and finally the profitability levels were tried to be revealed.

Cost and income factors were priced at current market prices in the region for 2018 and 2019 (Table 3). While pricing alternative cost method has been used in labor activities that require machine labor such as tillage, spraying, fertilization operations that require only human labor such as summer and winter pruning, hoeing yield adjustment, grape and leaf harvesting opearations are priced over the labor wage corresponding to the duration of the work.

In Table 4 and Table 5, the production costs of one decare of vineyards in 2018 and 2019 are shown. Production costs in 2018 were between 1.912,84-2.281,60 TRY. While the lowest model is only the grape production model, the highest model is the model in only leaf. In 2019, only the grape production model was again the lowest with 2.325,58 TRY. The model (L7-G50), only leaves harvest, has the highest production cost with 2.762,88 TRY.
In Table 6 and Table 7, the distribution of production costs according to cost elements can be seen. Although it varies slightly according to production models, the rate of variable costs is between $64.8-74.7 \%$ in both years. The biggest cost element among variable costs is the soil cultivation costs. $18.7-24.9 \%$ of total production costs are spent on soil cultivation activities. Other expenses (fixed expenses) consisting of capital interest, general expenses, land rent, and depreciation are between 25.3-35.2\%. Leaf harvesting labor costs are the biggest cost element only in the leaf production model. Leaf harvesting labor costs constitute $20.3 \%$ of the production costs in the first year of the study and $22.7 \%$ in the second year. In the first year of the study, drug expenditures were $15.3 \%$ in this model and $17.8 \%$ in the second year. In addition, when disinfection labor is included, plant protection activities are the biggest expense item in other than leaf model only all grape production models. The share of the grape harvest labor expense in the production costs is 
Table 4. Vineyard production costs per decare (2018 Year; TRY)

\begin{tabular}{|c|c|c|c|c|c|c|}
\hline & \multicolumn{6}{|c|}{ Production Models } \\
\hline & L3-G100 & L3-G75 & L3-G50 & L3-G25 & L5-G100 & L5-G75 \\
\hline Winter pruning labor & 80.43 & 80.43 & 80.43 & 80.43 & 80.43 & 80.43 \\
\hline Tilling & 427.42 & 427.42 & 427.42 & 427.42 & 427.42 & 427.42 \\
\hline Fertilization labor & 10.00 & 10.00 & 10.00 & 10.00 & 10.00 & 10.00 \\
\hline Summer pruning labor & 150.06 & 191.61 & 208.23 & 236.08 & 150.06 & 192.63 \\
\hline Plant productions labor & 105.00 & 105.00 & 105.00 & 105.00 & 109.00 & 109.00 \\
\hline Leaf harvesting labor & 91.00 & 104.00 & 102.00 & 114.00 & 124.00 & 175.00 \\
\hline Grape harvesting labor & 41.00 & 28.00 & 24.00 & 20.00 & 35.00 & 27.00 \\
\hline Pesticides & 254.36 & 254.36 & 254.36 & 254.36 & 291.36 & 291.36 \\
\hline Fertilizer & 42.00 & 42.00 & 42.00 & 42.00 & 42.00 & 42.00 \\
\hline Capital interest & 84.09 & 87.00 & 87.74 & 90.25 & 88.85 & 94.84 \\
\hline Total variable costs & $1.285,36$ & $1.329,82$ & $1.341,18$ & $1.379,54$ & $1.358,12$ & $1.449,68$ \\
\hline Total fixed costs & 675.36 & 676.69 & 677.04 & 678.19 & 677.54 & 680.29 \\
\hline \multirow[t]{2}{*}{ Total production costs } & $1.960,72$ & $2.006,51$ & $2.018,22$ & $2.057,73$ & $2.035,66$ & $2.129,97$ \\
\hline & L5-G50 & L5-G25 & L7-G50 & L7-G25 & $\mathbf{L}$ & G \\
\hline Winter pruning labor & 80.43 & 80.43 & 80.43 & 80.43 & 80.43 & 80.43 \\
\hline Tilling & 427.42 & 427.42 & 427.42 & 427.42 & 427.42 & 427.42 \\
\hline Fertilization labor & 10.00 & 10.00 & 10.00 & 10.00 & 10.00 & 10.00 \\
\hline Summer pruning labor & 205.17 & 216.84 & 207.80 & 225.58 & 184.47 & 161.72 \\
\hline Plant productions labor & 109.00 & 109.00 & 114.00 & 114.00 & 129.00 & 114.00 \\
\hline Leaf harvesting labor & 203.00 & 188.00 & 286.00 & 261.00 & 463.00 & 0.00 \\
\hline Grape harvesting labor & 27.00 & 20.00 & 16.00 & 21.00 & 0.00 & 29.00 \\
\hline Pesticides & 291.36 & 291.36 & 293.26 & 293.26 & 156.10 & 293.26 \\
\hline Fertilizer & 42.00 & 42.00 & 42.00 & 42.00 & 42.00 & 42.00 \\
\hline Capital interest & 97.68 & 96.95 & 103.38 & 103.23 & 104.47 & 81.05 \\
\hline Total variable costs & $1.493,06$ & $1.482,00$ & $1.580,29$ & $1.577,92$ & $1.596,89$ & $1.238,88$ \\
\hline Total fixed costs & 681.59 & 681.26 & 684.21 & 684.14 & 684.71 & 673.97 \\
\hline Total production costs & $2.174,65$ & $2.163,26$ & $2.264,50$ & $2.262,06$ & $2.281,60$ & $1.912,84$ \\
\hline
\end{tabular}


Table 5 Distribution of vineyard production cost elements per decare (2018 Year; \%)

\begin{tabular}{|c|c|c|c|c|c|c|}
\hline & \multicolumn{6}{|c|}{ Production Models } \\
\hline & L3-G100 & L3-G75 & L3-G50 & L3-G25 & L5-G100 & L5-G75 \\
\hline Winter pruning labor & 4.1 & 4.0 & 4.0 & 3.9 & 4.0 & 3.8 \\
\hline Tilling & 4.8 & 4.7 & 4.7 & 4.6 & 4.7 & 4.5 \\
\hline Fertilization labor & 0.5 & 0.5 & 0.5 & 0.5 & 0.5 & 0.5 \\
\hline Summer pruning labor & 17.0 & 16.6 & 16.5 & 16.2 & 16.3 & 15.6 \\
\hline Plant productions labor & 7.7 & 9.5 & 10.3 & 11.5 & 7.4 & 9.0 \\
\hline Leaf harvesting labor & 5.4 & 5.2 & 5.2 & 5.1 & 5.4 & 5.1 \\
\hline Grape harvesting labor & 4.6 & 5.2 & 5.1 & 5.5 & 6.1 & 8.2 \\
\hline Pesticides & 13.0 & 12.7 & 12.6 & 12.4 & 14.3 & 13.7 \\
\hline Fertilizer & 2.1 & 2.1 & 2.1 & 2.0 & 2.1 & 2.0 \\
\hline Capital interest & 4.3 & 4.3 & 4.3 & 4.4 & 4.4 & 4.5 \\
\hline Total variable costs & 65.6 & 66.3 & 66.5 & 67.0 & 66.7 & 68.1 \\
\hline Total fixed costs & 34.4 & 33.7 & 33.5 & 33.0 & 33.3 & 31.9 \\
\hline \multirow[t]{2}{*}{ Total production costs } & 100.0 & 100.0 & 100.0 & 100.0 & 100.0 & 100.0 \\
\hline & L5-G50 & L5-G25 & L7-G50 & L7-G25 & $\mathbf{L}$ & $\mathbf{G}$ \\
\hline Winter pruning labor & 3.7 & 3.7 & 3.6 & 3.6 & 3.5 & 4.2 \\
\hline Tilling & 4.4 & 4.4 & 4.2 & 4.2 & 4.2 & 5.0 \\
\hline Fertilization labor & 0.5 & 0.5 & 0.4 & 0.4 & 0.4 & 0.5 \\
\hline Summer pruning labor & 15.3 & 15.4 & 14.7 & 14.7 & 14.6 & 17.4 \\
\hline Plant productions labor & 9.4 & 10.0 & 9.2 & 10.0 & 8.1 & 8.5 \\
\hline Leaf harvesting labor & 5.0 & 5.0 & 5.0 & 5.0 & 5.7 & 6.0 \\
\hline Grape harvesting labor & 9.3 & 8.7 & 12.6 & 11.5 & 20.3 & 0.0 \\
\hline Pesticides & 13.4 & 13.5 & 13.0 & 13.0 & 6.8 & 15.3 \\
\hline Fertilizer & 1.9 & 1.9 & 1.9 & 1.9 & 1.8 & 2.2 \\
\hline Capital interest & 4.5 & 4.5 & 4.6 & 4.6 & 4.6 & 4.2 \\
\hline Total variable costs & 68.7 & 68.5 & 69.8 & 69.8 & 70.0 & 64.8 \\
\hline Total fixed costs & 31.3 & 31.5 & 30.2 & 30.2 & 30.0 & 35.2 \\
\hline Total production costs & 100.0 & 100.0 & 100.0 & 100.0 & 100.0 & 100.0 \\
\hline
\end{tabular}


Table 6. Vineyard production costs per decare (2019 Year; TRY)

\begin{tabular}{|c|c|c|c|c|c|c|}
\hline & \multicolumn{6}{|c|}{ Production Models } \\
\hline & L3-G100 & L3-G75 & L3-G50 & L3-G25 & L5-G100 & L5-G75 \\
\hline Winter pruning labor & 63.91 & 63.91 & 63.91 & 63.91 & 63.91 & 63.91 \\
\hline Tilling & 580.00 & 580.00 & 580.00 & 580.00 & 580.00 & 580.00 \\
\hline Fertilization labor & 10.00 & 10.00 & 10.00 & 10.00 & 10.00 & 10.00 \\
\hline Summer pruning labor & 171.6 & 244.05 & 264.53 & 303.34 & 171.6 & 227.74 \\
\hline Plant productions labor & 160 & 160 & 160 & 160 & 160 & 160 \\
\hline Leaf harvesting labor & 110 & 108 & 109 & 146 & 204 & 213 \\
\hline Grape harvesting labor & 44 & 44 & 29 & 21 & 46 & 39 \\
\hline Pesticides & 414.42 & 414.42 & 414.42 & 414.42 & 414.42 & 414.42 \\
\hline Fertilizer & 43.4 & 43.4 & 43.4 & 43.4 & 43.4 & 43.4 \\
\hline Capital interest & 111.81 & 116.74 & 117.2 & 121.94 & 118.53 & 122.6 \\
\hline Total variable costs & $1.709,14$ & $1.784,52$ & $1.791,46$ & $1.864,01$ & $1.811,86$ & $1.874,07$ \\
\hline Total fixed costs & 688.07 & 690.34 & 690.54 & 692.72 & 691.16 & 693.02 \\
\hline \multirow[t]{2}{*}{ Total production costs } & $2.397,22$ & $2.474,86$ & $2.482,00$ & $2.556,74$ & $2.503,02$ & $2.567,10$ \\
\hline & L5-G50 & L5-G25 & L7-G50 & L7-G25 & $\mathbf{L}$ & $\mathbf{G}$ \\
\hline Winter pruning labor & 63.91 & 63.91 & 63.91 & 63.91 & 63.91 & 63.91 \\
\hline Tilling & 580.00 & 580.00 & 580.00 & 580.00 & 580.00 & 580.00 \\
\hline Fertilization labor & 10.00 & 10.00 & 10.00 & 10.00 & 10.00 & 10.00 \\
\hline Summer pruning labor & 229.76 & 298.16 & 271.39 & 265.58 & 111.87 & 186.6 \\
\hline Plant productions labor & 160 & 160 & 160 & 160 & 130 & 160 \\
\hline Leaf harvesting labor & 241 & 243 & 356 & 293 & 568 & 0 \\
\hline Grape harvesting labor & 24 & 19 & 30 & 16 & 0 & 74 \\
\hline Pesticides & 414.42 & 414.42 & 414.42 & 414.42 & 184.77 & 414.42 \\
\hline Fertilizer & 43.4 & 43.4 & 43.4 & 43.4 & 43.4 & 43.4 \\
\hline Capital interest & 123.65 & 128.23 & 135.04 & 129.24 & 118.44 & 107.26 \\
\hline Total variable costs & $1.890,14$ & $1.960,12$ & $2.064,16$ & $1.975,55$ & $1.810,39$ & $1.639,59$ \\
\hline Total fixed costs & 693.5 & 695.6 & 698.72 & 696.07 & 691.11 & 685.99 \\
\hline Total production costs & $2.583,65$ & $2.655,73$ & $2.762,88$ & $2.671,62$ & $2.501,50$ & $2.325,58$ \\
\hline
\end{tabular}


Table 7. Distribution of vineyard production cost elements per decare (2019 Year; \%)

\begin{tabular}{|c|c|c|c|c|c|c|}
\hline & \multicolumn{6}{|c|}{ Production Models } \\
\hline & L3-G100 & L3-G75 & L3-G50 & L3-G25 & L5-G100 & L5-G75 \\
\hline Winter pruning labor & 2.7 & 2.6 & 2.6 & 2.5 & 2.6 & 2.5 \\
\hline Tilling & 24.2 & 23.4 & 23.4 & 22.7 & 23.2 & 22.6 \\
\hline Fertilization labor & 0.4 & 0.4 & 0.4 & 0.4 & 0.4 & 0.4 \\
\hline Summer pruning labor & 7.2 & 9.9 & 10.7 & 11.9 & 6.9 & 8.9 \\
\hline Plant productions labor & 6.7 & 6.5 & 6.4 & 6.3 & 6.4 & 6.2 \\
\hline Leaf harvesting labor & 4.6 & 4.4 & 4.4 & 5.7 & 8.2 & 8.3 \\
\hline Grape harvesting labor & 1.8 & 1.8 & 1.2 & 0.8 & 1.8 & 1.5 \\
\hline Pesticides & 17.3 & 16.7 & 16.7 & 16.2 & 16.6 & 16.1 \\
\hline Fertilizer & 1.8 & 1.8 & 1.7 & 1.7 & 1.7 & 1.7 \\
\hline Capital interest & 4.7 & 4.7 & 4.7 & 4.8 & 4.7 & 4.8 \\
\hline Total variable costs & 71.3 & 72.1 & 72.2 & 72.9 & 72.4 & 73.0 \\
\hline Total fixed costs & 28.7 & 27.9 & 27.8 & 27.1 & 27.6 & 27.0 \\
\hline \multirow[t]{2}{*}{ Total production costs } & 100.0 & 100.0 & 100.0 & 100.0 & 100.0 & 100.0 \\
\hline & L5-G50 & L5-G25 & L7-G50 & L7-G25 & $\mathbf{L}$ & $\mathbf{G}$ \\
\hline Winter pruning labor & 2.5 & 2.4 & 2.3 & 2.4 & 2.6 & 2.7 \\
\hline Tilling & 22.4 & 21.8 & 21.0 & 21.7 & 23.2 & 24.9 \\
\hline Fertilization labor & 0.4 & 0.4 & 0.4 & 0.4 & 0.4 & 0.4 \\
\hline Summer pruning labor & 8.9 & 11.2 & 9.8 & 9.9 & 4.5 & 8.0 \\
\hline Plant productions labor & 6.2 & 6.0 & 5.8 & 6.0 & 5.2 & 6.9 \\
\hline Leaf harvesting labor & 9.3 & 9.2 & 12.9 & 11.0 & 22.7 & 0.0 \\
\hline Grape harvesting labor & 0.9 & 0.7 & 1.1 & 0.6 & 0.0 & 3.2 \\
\hline Pesticides & 16.0 & 15.6 & 15.0 & 15.5 & 7.4 & 17.8 \\
\hline Fertilizer & 1.7 & 1.6 & 1.6 & 1.6 & 1.7 & 1.9 \\
\hline Capital interest & 4.8 & 4.8 & 4.9 & 4.8 & 4.7 & 4.6 \\
\hline Total variable costs & 73.2 & 73.8 & 74.7 & 73.9 & 72.4 & 70.5 \\
\hline Total fixed costs & 26.8 & 26.2 & 25.3 & 26.1 & 27.6 & 29.5 \\
\hline Total production costs & 100.0 & 100.0 & 100.0 & 100.0 & 100.0 & 100.0 \\
\hline
\end{tabular}

Table 8. Economic analysis (2018 Year)

\begin{tabular}{llllllll}
\hline $\begin{array}{l}\text { Production } \\
\text { Models }\end{array}$ & $\begin{array}{l}\text { GPV } \\
\text { (TRY) }\end{array}$ & $\begin{array}{l}\text { Variable } \\
\text { Expenses } \\
\text { (TRY) }\end{array}$ & $\begin{array}{l}\text { Fixed } \\
\text { Costs } \\
\text { (TRY) }\end{array}$ & $\begin{array}{l}\text { Gross } \\
\text { Profit } \\
\text { (TRY) }\end{array}$ & $\begin{array}{l}\text { Production } \\
\text { Costs } \\
\text { (TRY) }\end{array}$ & $\begin{array}{l}\text { Net } \\
\text { Profit } \\
\text { (TRY) }\end{array}$ & $\begin{array}{l}\text { Proportional } \\
\text { Profit }\end{array}$ \\
\hline L3-G100 & $2.897,4$ & $1.285,4$ & 675,36 & $1.612,0$ & $1.960,7$ & 936,7 & 1,48 \\
L3-G75 & $2.357,9$ & $1.329,8$ & 676,69 & $1.028,1$ & $2.006,5$ & 351,4 & 1,18 \\
L3-G50 & $2.376,7$ & $1.341,2$ & 677,04 & $1.035,5$ & $2.018,2$ & 358,5 & 1,18 \\
L3-G25 & $2.224,7$ & $1.379,5$ & 678,19 & 845,1 & $2.057,7$ & 166,9 & 1,08 \\
L5-G100 & $3.202,1$ & $1.358,1$ & 677,54 & $1.844,0$ & $2.035,7$ & $1.166,5$ & 1,57 \\
L5-G75 & $2.940,2$ & $1.449,7$ & 680,29 & $1.490,6$ & $2.130,0$ & 810,3 & 1,38 \\
L5-G50 & $3.210,0$ & $1.493,1$ & 681,59 & $1.717,0$ & $2.174,6$ & $1.035,4$ & 1,48 \\
L5-G25 & $2.451,2$ & $1.482,0$ & 681,26 & 969,2 & $2.163,3$ & 288,0 & 1,13 \\
L7-G50 & $3.073,7$ & $1.580,3$ & 684,21 & $1.493,4$ & $2.264,5$ & 809,2 & 1,36 \\
L7-G25 & $2.652,0$ & $1.577,9$ & 684,14 & $1.074,1$ & $2.262,1$ & 389,9 & 1,17 \\
L & $2.234,5$ & $1.596,9$ & 684,71 & 637,6 & $2.281,6$ & $-47,1$ & 0,98 \\
G & $2.460,5$ & $1.238,9$ & 673,97 & $1.221,6$ & $1.912,8$ & 547,7 & 1,29 \\
\hline
\end{tabular}


Table 9. Economic analysis (2019 Year)

\begin{tabular}{llllllll}
\hline $\begin{array}{l}\text { Production } \\
\text { Models }\end{array}$ & $\begin{array}{l}\text { GPV } \\
\text { (TRY) }\end{array}$ & $\begin{array}{l}\text { Variable } \\
\text { Expenses } \\
\text { (TRY) }\end{array}$ & $\begin{array}{l}\text { Fixed } \\
\text { Costs } \\
\text { (TRY) }\end{array}$ & $\begin{array}{l}\text { Gross } \\
\text { Profit } \\
\text { (TRY) }\end{array}$ & $\begin{array}{l}\text { Production } \\
\text { Costs } \\
\text { (TRY) }\end{array}$ & $\begin{array}{l}\text { Net } \\
\text { Profit } \\
\text { (TRY) }\end{array}$ & $\begin{array}{l}\text { Proportional } \\
\text { Profit }\end{array}$ \\
\hline L3-G100 & $3.610,9$ & $1.709,1$ & 688,07 & $1.901,8$ & $2.397,2$ & $1.213,7$ & 1.51 \\
L3-G75 & $3.274,7$ & $1.784,5$ & 690,34 & $1.490,2$ & $2.474,9$ & 799,8 & 1.32 \\
L3-G50 & $5.331,3$ & $1.791,5$ & 690,54 & $3.539,8$ & $2.482,0$ & $2.849,3$ & 2.15 \\
L3-G25 & $4.444,2$ & $1.864,0$ & 692,72 & $2.580,2$ & $2.556,7$ & $1.887,5$ & 1.74 \\
L5-G100 & $3.961,9$ & $1.811,9$ & 691,16 & $2.150,0$ & $2.503,0$ & $1.458,9$ & 1.58 \\
L5-G75 & $4.147,4$ & $1.874,1$ & 693,02 & $2.273,3$ & $2.567,1$ & $1.580,3$ & 1.62 \\
L5-G50 & $5.848,1$ & $1.890,1$ & 693,5 & $3.958,0$ & $2.583,7$ & $3.264,5$ & 2.26 \\
L5-G25 & $4.381,3$ & $1.960,1$ & 695,6 & $2.421,2$ & $2.655,7$ & $1.725,6$ & 1.65 \\
L7-G50 & $7.427,2$ & $2.064,2$ & 698,72 & $5.363,0$ & $2.762,9$ & $4.664,3$ & 2.69 \\
L7-G25 & $4.979,8$ & $1.975,6$ & 696,07 & $3.004,3$ & $2.671,6$ & $2.308,2$ & 1.86 \\
L & $3.749,0$ & $1.810,4$ & 691,11 & $1.938,6$ & $2.501,5$ & $1.247,5$ & 1.50 \\
G & $4.022,2$ & $1.639,6$ & 685,99 & $2.382,6$ & $2.325,6$ & $1.696,6$ & 1.73 \\
\hline
\end{tabular}

between $0.6-2.1 \%$. although it varies according to the rate of leaving the grape on the vine in the grape production targeted models. Fertilization, summer pruning, and winter pruning cost factors have small differences according to production models.

In Table 8 and Table 9, as the result of economic analysis of production models, production and variable costs, as well as gross profit, net profits, and proportional profit, can be seen. In the first year of the study, the highest net profit was L5-G100 with 1.166,5 TRY, and the lowest was the model with L with -47.1 TRY. In the second year of the study, a high net profit was obtained from the L7-G50 production model with 4.664,3 TRY and the lowest with 799,8 TRY from the L3-G75 production model. The L3-G25 model, which had the lowest net profit and only grape molasses was bought in the previous year, showed an exceptional net profitability in the second year with grape yield suitable for wine grapes and it surpassed the L5G100 model with the highest net profit in the previous year. On the other hand, the L5-G50 application maintained its second place in terms of net profitability in the second year (Table 9). The model with only leaves harvest was proportional profitability in the first year 0.98 and in the second year 1.50. The highest profitability0 belonged to L5-G100 (1.57) in the first year and L7-G50 (2.69) in the second year.
Especially, the increase in models where the grape is reduced by $50 \%$ is noteworthy, and this is due to the fact that grapes can be evaluated as wine in these models.

\section{Conclusions}

In the first year of the study, the production model in which all the grapes were left and the leaves were harvested 5 times; It was the model that showed the highest values with a net profit of 1.166,5 TRY da-1 and a proportional profitability of 1.57 . In the second year of the study, the model, in which the grapes were left at a rate of $50 \%$ and the leaves were harvested 7 times, became the economically recommended variety for producers with a net profit of $4.664,32$ TRY $\mathrm{da}^{-1}$ and proportional profitability of 2.69 . However, the production model that can be carried out together without sacrificing leaf and grape quality in both years of the study was L7G50 (7 times leaf harvest and a maximum 50\% reduction of the grape) was the economically recommended model. L5-G50 (5 times leaf harvest and $50 \%$ reduction of grape) was found as a technically recommended model.

When it is aimed to carry out grape and leaf cultivation together, spraying costs are the biggest expense factor in total variable costs for struggling with diseases and pests. In addition, hoeing labor costs for weed control is also an 
important cost element in the costs. In production models where grape and leaf production are carried out together, leaf harvesting labor is the second most important cost element in total costs after spraying, depending on the number of leaf harvesting. In the production model for leaf harvest only, it has a ratio of $20.3-22.7 \%$ within the total costs.

The share of $1 \mathrm{~kg}$ of leaves in the harvest labor sales price is $19.6 \%$. A male worker can harvest about $34 \mathrm{~kg}$ of leaves in a day, depending on the shapes given to the vinestocks in the vineyard. There were no differences in terms of leaf quality between the production patterns with leaf harvesting and between the leaf harvest dates.

Grape quality varies according to production models, and it has been determined that the grape quality is higher in the production models reduced by $25 \%$ and $50 \%$ grape harvest.

It will be possible to harvest more leaves per unit area only by selecting the thickset planting, cultivation and pruning method in the vineyard facility for leaf production. However, further studies should be done to determine them

\section{Acknowledgments}

The authors thank all editors, reviewers who read and contributed to the final version of the text.

\section{Author Contribution}

Authors MAK and MAŞ have planned the general disposition of the manuscript. UA made structural revisions of the manuscript. All authors read and approved the final manuscript

\section{Conflicts of Interest}

The authors declare that there is no conflict of interest.

\section{REFERENCES}

Birinci, A., \& Er, K. (2006). A Research on Economic Comparison and Marketing of Organic and Conventional Peach Production in Bursa Province Karacabey District. Agricultural Economics Association (TAREKODER), http://www.tarekoder. org/webfolders/files/2006_1_03.pdf Date of access: 14.05.2008.

Cangi, R., Adınır, M., Yağcı, A., Topçu, N., \& Sucu, S. (2011). Economic analysis of different production models in vineyard producted brined-grape (in Turkish with English abstract). Journal of Iğdır University Institute of Science and Technology 1(2), 77-84.

Çelik, H., Kunter, B., Söylemezoğlu, G., Ergül, A., Çelik, H., Karataş, H., Özdemir, G. \& Atak, A. (2010). Development Methods and Production Targets of Viticulture. ZMO VII. Technical Congress 11-15 January, 2010. Ankara 493-513 p.

Demircan, V., Yılmaz, H., \& Binici, T. (2005). Determination of Apple Production Cost and Income in Isparta Province. Agricultural Economics Association (TAREKODER), http://www. tarekoder.org/webfolders/files/2005_2_02.pdf ; Date of access: 14.05.2008.

TUIK. (2017). Turkish Patent and Trademark Office website, https://www.ci.gov.tr/Files/GeographicalSigns/258.pdf Date of access: 15.12 .2020

TUIK. (2019). Turkey Statistics Institute website, Foreign Trade Statistics, https://biruni.tuik.gov.tr/disticaretapp/menu.zul Date of access: 15.12 .2020

Winkler, A. J., Cook, J. A., Kliewer, W. M., \& Lider L. A. (1974). General Viticulture. University of California Press. 710 p. 